fully water-borne the vessel is in stable equilibrium, and the turning right side uppermost is accomplished by permitting the air to escape from the interior; the vessel sinks in the water until a draught is reached for which the equilibrium becomes unstable, and the vessel then turns over without further aid until the deck is uppermost. Fig. 2 shows the vessel with the turning operation about half accomplished, and in Fig. 3 the vessel is seen floating in its ordinary position.

The first vessel took about six weeks to arrange the boarding and reinforcement, and two days to cast; three weeks were allowed for the concrete to set. It is estimated that the next vessel can be done in half the time, since the same shuttering can be used again.

\section{W. DU BOIS DUDDELL, C.B.E., F.R.S.}

THE death of William Du Bois Duddell on 1 November 4, at forty-five years of age, leaves a gap in the ranks of our men of science which it will be difficult to fill. His was a rare and precious gift, for he had, in the highest degree, extraordinary patience and scientific instinct. When a problem was set him, however difficult, however insoluble it might appear to be at first, he was never satisfied until he had obtained a solution. It was an inspiration for anyone to have the privilege of helping him in a piece of scientific work. I shall always remember the development of his oscillograph. We were working together on the study of the alternate current arc and were using a laborious " point by point" method for obtaining the curves of current and potential difference. He had set his mind on the production of an instrument that would record the curves instantaneously, and at this problem he worked continuously. He made the first instrument in his workshop at home and brought it along to test; the damping was unsatisfactory, and we set to work to find a method of damping that was efficient. In the end he made a separate channel, with incredibly thin walls, for each strip, and succeeded. It was remarkable that, although the first instrument was designed by eye, the final form of the oscillograph, so far as the vibrator was concerned, did not differ very much in its principal dimensions from the original instrument. Theory enabled the best conditions to be determined, but a full understanding of theory did not lead to a very great improvement. Duddell's instinct as a designer gave the right dimensions from the start. No one who saw it will forget the demonstration that was given by Duddell before the Institution of Electrical Engineers of his instrument, perfect in every detail. There is no doubt that its production marked an epoch in the experimental investigation of alternating current phenomena. If genius is an infinite capacity for taking pains, then Duddell had genius of the very highest kind, for his patience was boundless. His gift as an instrument- maker was hereditary, for he was connected with the great Du Bois family, famous in that home of watchmaking, Switzerland, for its products.

Duddell's rise to the front rank of scientific men was meteoric. Soon after his paper on oscillographs (the first edition of which had been given before the British Association in Toronto) he read a classical paper on the resistance of the electric arc before the Royal Society. It was in the course of this work that he discovered the " singing arc," which formed the starting point in the development of the Poulsen arc, now so largely used in wireless telegraphy, and built the first really high frequency alternator. It was necessary, in order to prove his theory, that a current should be sent through the arc of such a frequency that sensible variations in the temperature of the arc could not be produced by it, so he designed and built an alternator giving I20,000 cycles per second, a frequency which at that time no one had attempted to produce by a mechanical alternator.

Not only was Duddell's gift as an inventor of the highest order; he had also rare skill as an experimenter; his experiments always worked. I can never remember having seen a lecture experiment of his that failed, while his power of talking clearly was a gift possessed by few; he reached, I think, almost the highest point in his career as a lecturer in the demonstration on "Pressure Rises " that he gave when he was elected president of the Institution of Electrical Engineers for the second time. The experiments were nearly all difficult, and liable to go wrong, but they all succeeded, and his model of the oscillating arc was a triumph of demonstration.

Duddell was made a fellow of the Royal Society in 1907 , and his was one of the few cases in which election took place at the first time of asking, for he was elected on the first occasion on which his name appeared on the list of prospective new fellows. In ror 2 he was awarded the Hughes medal. He was president of the Commission Internationale de Télégraphie sans Fil. In 1907 he was president of the Röntgen Society, and had been hon. treasurer of the Physical Society since r9ı. He was a member of the Advisory Council to the Department of Scientific and Industrial Research and of the Board of Inventions and Research of the Admiralty. Last August the honour of Commander of the Order of the British Empire was conferred upon him.

As a chairman of committees Duddell was always excellent, being businesslike and to the point; no time was ever wasted when he was in charge. He was no mean linguist, and those who have seen him conduct an international conference will remember his gifts, and the infinite tact with which he was always able to reconcile the differing points of view and characteristics of men of different nationalities. It is an unspeakable grief to his friends that he has died so young, though few men have ever achieved so much in so short a time; but he worked himself to death. He was always in his laboratory or his office; he scarcely NO. 2507 , VOL. IOO] 
ever took a holiday. He was at school at Cannes, and at that time the French took less interest in sports and games than they do now, so that he had none of that love for outdoor pursuits which is so characteristic of the average Englishman. He had no enemies, for everyone who knew him liked him for his kindliness and his extraordinary modesty, though, when the occasion arose, he could show great firmness and decision. He will long be remembered as a great man of science and a great gentleman.

E. W. Marchant.

\section{NOTES.}

IN its column entitled "Through German Eyes," the Times of November I3 gives prominence to notices appearing in German newspapers of further important steps now being taken to strengthen and consolidate the great dye syndicate, of which the seven largest firms control a capital of nearly $12,000,000 l$. The three largest undertakings in this group, namely, the Höchst colour works, the Badische Anilin- und SodaFabrik, and the Bäyer colour factories, are each to increase their capital from $2,700,000 l$. to $4,500,000 l$. These increases of capital, raised by the Rhenish firms themselves, will be supplemented by additional sums to be provided by the German Government, so that the total capital will be more than $20,000,000 l$. The German Press appreciates fully the prominent part played by chemical industry in the war, and attributes largely to this group of factories the extraordinary striking force displayed by Germany on the fields of battle. The intimate relationship between synthetic dyes and high explosives has slowly dawned on the British public, but it is deplorable that even after three years of war the English colour industry is in a position even more disorganised and chaotic than it was at the outbreak of hostilities. A beginning of co-ordination and caoperation in dye production has developed among the Lancashire firms, but the State-aided company which was to have united the colour trade and to have administered the research grant of $120,000 l$. for the benefit of all the manufacturers concerned, so far from effecting these vital improvements, has actually been the direct exciting cause of additional friction and needless internal competition. Now that public appeals are being made for more Government support for this company it is surely time that a non-political, impartial Parliamentary inquiry should be set on foot to ascertain how the earlier grants have been expended, and whether the existing organisation is adequate to meet the competition of a powerful enemy syndicate operating under expert and scientific management.

IN a speech delivered on November 8 the President of the Board of Agriculture again directed public attention to the gravity of the food outlook, and outlined clearly the concatenation of circumstances which render it inevitable that even the establishment of peace cannot bring automatically the proverbially associated plenty. Of special interest was Mr. Prothero's warning that the productive power of the soil of Europe is falling. Not only have large cultivated areas become desolate wastes through the direct ravages of warfare, but even regions remote from the firing line are losing their fertility for want of labour and fertilisers. That is true of Germany; it is also true of areas in this country. Mr. Prothero pointed out that the yield per acre fell in 1916; it has fallen still further in 1917, and, so far as existing areas go, will almost certainly undergo a further decrease. On broad general grounds this prediction is doubtless reasonably probable, but statisticians will scarcely regard the results of the last two seasons as a sufficient basis for such a broad generalisa- tion, especially as these have been years in which natural conditions alone have notoriously been unfavourable to a heavy grain crop. The average yield of wheat per acre in England and Wales this year is estimated at 29.88 bushels, of barley at 30.36 bush., and of oats at 38.49 bush., as compared with 28.60 bush., 3 r-II bush., and 39.95 bush. respectively in 1916 , and averages of 31.40 bush., 32.44 bush., and 40.03 bush. respectively for the ten years $1907-16$. These differences are well within the range of natural variations, and can scarcely be adduced as evidence of specific decline in fertility. It is certain, however, that the increasing foulness of the arable land owing to lack of adequate labour for the necessary cleaning operations must tend totwards a reduction of crop. On the other hand, it is equally certain that an extended and more skilful use of fertilisers for corn crops would lead to an appreciable increase of the average yields. An instance in point is furnished by a report on oat manuring experiments recently issued by the West of Scotland Agricultural College, in which it is recorded that on the average of seventeen experiments in three years the oat yield of $4 \mathrm{I} \frac{\mathrm{x}}{4}$ bush. on the unmanured plot was increased fully 30 per cent. by the combined use of superphosphate, kainit, and sulphate of ammonia. The wheat crop offers probably less scope for intensive manuring, but undoubtedly is capable of very substantial improvement on many farms.

IT was remarked in these columns, at the time of the establishment of the Air Board, that more coordination was needed between the various branches of the Air Services, and that the Air Board should do much to secure this end. The introduction of the Air Force Bill shows that the Government now intends to make such co-ordination complete by the establishment of an Air Council, which is to enjoy a status similar to that of the Admiralty and the Army Council. The Times remarks that this is a landmark in the history not only of aviation in this country, but also of the armed forces of the Crown; for it formally recognises the air as a distinctive fighting element, and provides for the establishment of a third service, to be called the Air Force. Those whose labours lie in the field of scientific aeronautical research will welcome the new régime as a step of great importance. A closer connection is very desirable between scientific work and practical aircraft design, and there seems little doubt that this end will be achieved much more rapidly if the present air services are organised as a single force and controlled by one central council. It is, indeed, a triumph for aviation that in only a few years of development it should rise to such importance as to cause the creation of a third Service, and it is pleasing to reflect that scientific research has played a very important part in this rapid development of the new industry.

A RECENT lecture delivered by Major Astor, M.P., on "Health Problems and a State Ministry of Health," at the Royal Institute of Public Health, was the third of a series of lectures and discussions on public health problems under war and after-war conditions. Not unnaturally, on this occasion, the bulk of what the speaker, and those who took part in the discussion, had to say related to the Ministry of Health, and Major Astor, having declared that the Local Government Board, and not the Insurance Commission, would form the best nucleus for a Health Ministry, there was a tendency on the part of other speakers to take sides. Amongst those who showed no inclination to declare in favour of any particular body was Mr. H. A. L. Fisher, President of the Board of Education, who presided over the meeting, and remarked, in the course of his speech, that thcugh, as matters now stood, there was considerable possibility of overlapping, it did not

NO. 2507 , VOL. IOO] 